\title{
Terrorism Post 11 September 2001: The Economic Globalisation and Religion (Islamophobia) Perspective
}

\author{
Mahfudzah Mustafa, Zaid Ahmad, Jayum Anak Jawan, Mohd Sabri Md Nor, \\ Muhammad Helmi Othman
}

To Link this Article: http://dx.doi.org/10.6007/IJARBSS/v11-i11/11666

DOI:10.6007/IJARBSS/v11-i11/11666

Received: 02 September 2021, Revised: 04 October 2021, Accepted: 27 October 2021

Published Online: 24 November 2021

In-Text Citation: (Mustafa et al., 2021)

To Cite this Article: Mustafa, M., Ahmad, Z., Jawan, J. A., Nor, M. S. M., \& Othman, M. H. (2021). Terrorism Post 11 September 2001: The Economic Globalisation and Religion (Islamophobia) Perspective. International Journal of Academic Research in Business and Social Sciences, 11(11), 1862-1874.

Copyright: (c) 2021 The Author(s)

Published by Human Resource Management Academic Research Society (www.hrmars.com)

This article is published under the Creative Commons Attribution (CC BY 4.0) license. Anyone may reproduce, distribute, translate and create derivative works of this article (for both commercial and non0-commercial purposes), subject to full attribution to the original publication and authors. The full terms of this license may be seen at: http://creativecommons.org/licences/by/4.0/legalcode

Vol. 11, No. 11, 2021, Pg. $1862-1874$

Full Terms \& Conditions of access and use can be found at http://hrmars.com/index.php/pages/detail/publication-ethics 


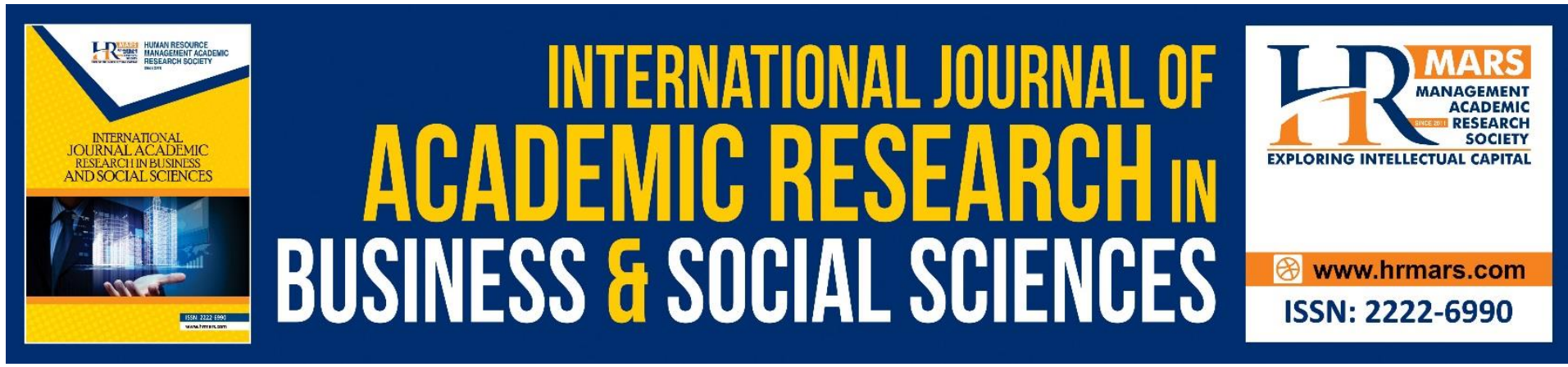

\title{
Terrorism Post 11 September 2001: The Economic Globalisation and Religion (Islamophobia) Perspective
}

\author{
Mahfudzah Mustafa, Zaid Ahmad, Jayum Anak Jawan, Mohd \\ Sabri Md Nor \\ Department of Government and Civilization Studies, Faculty of Human Ecology, \\ Universiti Putra Malaysia (UPM), 43400 Serdang, Selangor. \\ Corresponding Email: zaid_a@upm.edu.my \\ Email: adlidzah15@gmail.com,jayum@upm.edu.my,msabri@upm.edu.my.
}

\section{Muhammad Helmi Othman}

Center of Historical, Politics and International Affairs Studies (SPHEA), Faculty of Social Sciences and Humanities, Universiti Kebangsaan Malaysia (UKM) 43600 Bangi, Selangor.

Email: helmimpp.asp@gmail.com

\begin{abstract}
The end of Cold War has seen war as not only based on the question of ideology such as the clashes between socialism and capitalism, communism versus liberal democracy but it has radically changed into discourses and questions of identity, civilisations and religion. "War against Terrorism" sponsored by the United States of America has changed the paradigm of a majority of scholars in repositioning the concept of terrorism and the factors that lead to terrorism such as global Islamophobia. The existence of non-state actors such as Al Qaeda, DAESH or IS serves as indicators that non-state actors can challenge the state actors. Economic globalization also undeniably contributes as a factor to terrorism due to feelings of dissatisfaction towards the inequality and the gap among the nation-states. This study seeks to analyze the concept of terrorism after the 11 September 2001 event. This study further elaborates how the issues of globalization and religion became the pivot for terrorism activities. This study uses the qualitative method. The technique used is more towards analyzing comparatively or a discourse analysis on case studies relevant to the research. Primary and secondary data are also used.
\end{abstract}

Keywords: Terrorism, Globalization, Ideology, Religion, September 112001

\section{Introduction}

With the end of the Cold War in 1989, the world has fallen witness to the tremendous change in the international politics structure as communist-oriented Soviet Union crumbled. The triumph held by the liberal democrats has placed the US as the sole hegemonic power in the international system (Fukuyama, 1992). That said, the exponential pace of globalisation does 
not imply that conflicts have stopped happening. By contrast, the change of the world structure post-Cold War has spawned new security challenges involving regional conflicts, the proliferation of hostile and violent activities and hatred towards other ethnic groups. Huntington (1996), debates that in this new world, the conflict that is easily spread, the most important and the most precarious, is not among ideologies, social classes, rich or poor, or different economic groups, but one among those from different cultural entities. Prior to the 11 September 2001 event, the landscape was fabricated by the history of the Bosnia Herzegovina and Kosovo conflict in Balkan, the feuds of the Tamil and Sinhalese tribes in Sri Lanka and the battle between the Tutsi and Hutu in Rwanda and Burundi. The increased numbers of weaponry at a grand scale between nations and global terrorism have also created an increasingly overwhelming danger and damage to the global environments.

Terrorism is a concept that is often associated with any form of violence imposed on members of the society, locally or internationally. After the 11 September 2001 event, terrorism has been a hot issue often raised by international community who sympathises or criticises any violent activity that has happened, and is often happening, according to respective perspectives and ideologies. The sympathisers would opine that terrorism is self-liberation, the act of freeing a territory or nation from oppression. Meanwhile, the critics elaborate that it is a very inhuman act that sacrifices a lot of individuals not directly involved in the conflict. This relates to the composition of citizens, the US' external policy towards "terrorists" and the political movement associated with Islamic movement (Yazid, 2017).

This article explains about the concept of post-terrorism post-11 September. Other than that, this article will elaborate on the role of economic globalisation and the religious factor in influencing terrorism activity.

\section{Literature Review}

Published studies about terrorism have been greater in number, after the event of September 11 2001. Most have been published in the form of compilation that puts forth research based on different theoretical frameworks. The books published before the event are more comprehensive with regard to terrorism per se. In general, their study themes can be divided into three: i) discussion about terrorism in general : definition, causes and tactics used ; ii) terrorism and global order; and iii) terrorism in the framework of the international politics economy.

The book "The new global terrorism: characteristics, causes, controls" edited by Kegley (2003) is one of the books that highlights the main argument in the current debate about the threat of terrorism especially after $9 / 11$, and the methods that can be adopted to overcome these threats. It also summarises main concepts and the literature that focuses on the characteristics, causes and the controlling factors related to the current terrorism. Kegley (2003) is the writer of the introductory chapter in this book. His writing focuses more on the main product of 9/11 which is "the generation of fear" also new challenges of terrorism that need to be faced today. This is because he has the view that the practice of terrorism has been elevated to a new level rendering it more dangerous compared to how it was viewed previously. There exists a new rule in the terrorism "game" used by the weak towards the strong and this is implemented by "ideological terrorists with grandiose revolutionary ambitions acting transnationally to transform the international status quo" (Kegley, 2003). 
Currently, the act of terrorists is not only to scare the enemies away but also to annihilate and destroy them. Thus, Kegley (2003) states that 9/11 marks "the spectre of permanent terrorism throughout the globe, unless unchecked". He also issues a list that differentiates past terrorism activity and those after the 9/11 incident that have become the challenge to all, including the ruling party to think about new ways of curbing this new form of global terrorism. Similar to other scholars of terrorism phenomenon, Kegley, Jr also states that global terrorism is a multi-dimensional concept. Thus, to express this global terrorism in a definition will cover up its complex, diverse and ever-changing attributes. He concludes on the terrorist analysis in terms of the description, explanation for the cause and effect also the prescriptive that he finds intertwining. Thus, each of the analyses cannot be done in separation and independently (Kegley, 2003).

The book edited by Booth \& Dunne (2002) "Worlds in collision: terror and the future of global order" puts forth a collection of comprehensive and provocative views of several prominent scholars in their respective fields post-September 11, 2001. Among them is Francis Fukuyama who wrote the article "History and September 11". In this chapter, he has invited readers to think about why the event happened and to look at this new, violent challenge seriously. He raises the issue of the clash of civilizations- "cultural issues at play", although the administrations of Bush and Blair affirm that it is not connected to the issue of "the West vs Islam" - the logic behind the history, the difference between Islam and the West and the future in elaborating the causes for the possibility that there might be another event similar to September 11. Fukuyama concludes that to avoid the same thing from happening again, both the West and Islam have to fix the situation, including their relationship beginning from their standpoints, as "the struggle between Western liberal democracy and Islamo-fascism is not one between two equally viable cultural systems, both of which can master modern science and technology, create wealth and deal with the de facto diversity of the contemporary world. In all these respect, Western institutions hold all the cards and for that reason will continue to spread across the globe in the long run......to get to the long run we must survive the short run." Thus, the understanding about their each own ideologies must be explored.

Barro (2002) debates that poverty is not the root cause of terrorism. His debate is based on a study done by two researchers namely Krueger \& Maleckova in relation to the association between poverty and violence using the data obtained from a public voting at the West Bank and Gaza Strip by the Palestinian Center for Policy and Survey Research (PCPSR). The attack on America on September 11 shows that the plane hijackers are mostly from Saudi Arabia with high income per capita and level of education and this is strengthened by the finding in the work written by Krueger and Maleckova. He continues to offer his view that there might be a possibility that some form of education in the Middle Eastern region has the tendency to promote terrorism. Thus, Barro concludes that it is naive to think that the increased income and education will reduce international terrorism activities and proposes that the solution is to be undertaken at someplace else.

Bacevich (2001) sheds light on the information about the patterns of global terrorism in 2000 issued by The US National Department in April 2001. In general, he puts forth four basic principles of the US cooperation policy with its international members with regard to terrorism: i) cannot make any agreement or negotiation with terrorists: ii) must put terrorists 
to trial on their crime; iii) separate and exert pressure to countries that sponsor or advocate terrorism activities to coerce them into changing their approach and support; and iv) increase the counter-terrorists activity of countries cooperating with the US who seek for help. He also defines terrorism and the statistics that depict the increased number of international terrorist attacks and the number of victims involved. The tactic used by the terrorists is also stated including the number of anti-US approach, and also the double-standard practiced by the US with North Korea and Colombia that has violated the four basic principles of the US cooperation policy. Bacevich concludes that the increased terrorism especially one that is anti-US, should arouse fear and worry and give a form of signal to the US but he asks for what is there to worry about as only $13 \%$ of Americans who are truly concerned about this.

\section{Study Methodology}

This research is in the form of content analysis. It stresses on the use of materials or data that come from secondary sources, whereas the remaining data or the primary materials are taken from the mundane documentation and conversations in seminars and talks both locally and internationally. The study uses the secondary sources comprising of two forms - the works that elaborate on the theory and the concept proposed, and the works that analyse terrorism in the globalised era. Information from books, journals and thesis, also documents obtained from the website (that is able to explain more about the study sample) are also studied extensively. Thus, the methodology of finding and collecting materials is carried out through the research in the library, surfing the Internet, also through the personal collection of books bought at international book fairs and lecture notes.

\section{Study Outcome}

\section{Modernisation and Economic Globalisation Dilemma}

The modernisation and development of the global economy produces the westernization of culture. It fuels the re-emergence and consolidates the ties forged with natural cultures. At the individual level, people's migration to cities, the social environment and the yet-to-beidentified types of occupation will unravel the traditional local ties and create a sense of alienation plus anomy and further spawn an identity crisis that is connected to religious issues.

US President George W. Bush began to use the term "war against violence" on 16 September 2001 in his official speech to the Congress. In his previous speech, George Bush stated, "Our enemy is a radical network of terrorists and every government that supports them." This term was initially used with focus on countries that are linked to the al-Qaeda such as Afganistan and Iraq. As the 9/11 event happened on America's own land, it is not surprising that President George W. Bush declared "the global war against terrorism" immediately after it happened, inviting world countries to join him in this "crusade". Thus, it might be true that the 9/11 incident had opened the access for the reformation of international politics with the US as their leader, as depicted by Bush's declaration. In conclusion, the researcher's understanding on what is implied by "the reformation of world politics in the similar mould in terms of the scope" is that without the existence of Soviet Union, there is a great possibility that the US will act, and try their might to retain and broaden their influence and power in the political, economic and social fields. Thus, "scope" refers to the political, economic and social fields, whereas "the same mould" refers to the desire of the US to structure and dominate the international system using its own way or the way mentioned above. 
With the Western power retreating, the same goes with the appeal of the Western value and culture, and the West has to adapt itself to its deteriorating capability by imposing its values on the non-Western societies. Fundamentally speaking, a large part of the world is becoming more modern but less Westernised (Huntington, 1997). Nonetheless, the main choice remains to be uniformity (often termed "Americanization") and diversity. The outcome lies in the disappointment towards the world (in Max Weber's term) and the reaction against uniformity. The second outcome takes shape in the rebirth of local culture and language including the attack on the Western culture. The Western culture slammed as the arrogant advocate of a revolutionary and secular ideology is also seen as donning a mask of the US hegemony in carrying out re-colonization in this new era in a way that is more subtle and epistemological.

\section{The Failure of Economic Globalisation}

Stiglitz (2002) in his article entitled "Globalism's discontents" pays attention to the globalisation injustice and how it is addressed. He looks into the effect of globalisation especially on the policies of the International Monetary Fund (IMF) and the other international economic institutions that have given a negative impact on developing countries that have to comply with their policies. Stiglitz holds the opinion that the globalisation itself has been administered in undemocratic, non-advantageous ways to the developing countries, especially for the poor in the countries.

Karl Marx dan Friedrich Engels in their perspectives, had already held the prediction over capitalism in its current state. However, it ignites the main dilemma between efficacy and justice. The specification and integration of firms enable them to be the money-making machines but the logic of pure capitalism does not prioritise social justice. Thus, economic globalisation has become the root cause that contributes to the injustice among countries and in the country, and the concentration towards global competition has restricted the country's and other actors' tendency to resolve this issue. IMF has urged for the economic policy to be enforced, without looking into the society in a wider vision or economic role. The urge was done in ways that have affected the new democratic countries. The international economic institution administration is evidently more prone to fulfil the special interest of financial corporations and institutions. There seems to be non-existent democratic form of supervision to ensure that these non-official institutions work to serve the public interest and welfare. Thus, the effort to remove or exclude most of the global population from poverty has been in vain. Stemming from this, Stiglitz proposes a form of governance and transparency that is wider, more democratic and inclusive in the IMF and WTO which also include developing countries as to produce a type of globalisation that can benefit the majority of the global population (Jones, 2006).

By contrast, Guelke (1995) is firm in stating that the tension of the North-South relationship is the resource for terrorism to persist at the global level. The big gap of economy between developed and developing countries have created a big opportunity for demands that are larger in scope. International organisations are not an entity that can bridge the gap between the rich and the poor countries. At the same time, it is rather impossible to reduce the tension between the North and the South as it is ambiguous how the wider gap is to be reduced, or even closed. Guelke opines that the absence of political and economic resolve on the global inequality has created this sense of fear among the rich, developed countries. They are 
concerned that the confrontational sentiment brought forth by developing countries that has all the while been characteristically domestic, will become rampant and spread to their own countries. Thus, Guelke (1995) concludes that the economic inequality at the domestic and global level has a connection with political violence or terrorism.

Globalisation is also the cause for the re-emergence of personal international violence, especially one that has the potential to challenge the claim on the legitimate monopoly of the coercion instrument often associated with the concept of sovereignty (Payne, 2003). The attack on the World Trade Center on 9/11 in 2001 has been regarded by many critics as a new era of the global terrorism. The link between Western globalisation and violence globalisation has become too tight. Held and McGrew (2002), take the view that the Western globalisation has prepared some resources and half of the motivation for global violence, whereas the violence and the war against violence represent the boundaries and a set of new challenges towards global integration.

The 11 September incident is a watershed or a significant point that the issues of violence that previously revolved around the questions of state terrorism or state sponsored terrorism have shifted to individual issues, or the non state actor who does not own its complete set of weaponry have challenged, shocked and even "hurt" the great powers of the world. This attack shows that amid all these achievements, globalisation has caused terrorist groups to easily obtain and activate another form of violence. Terrorism is a bloody linkage between the international and global societies. When countless individuals and groups become global actors in line with other countries, the tendency to become unsafe and vulnerable to attacks is higher (Hoffmann, 2003). Other than that, with the rapid pace of ICT technology, helped by advancement in the communication field, this has even spurred violent activities. Terrorists can operate any time they want and wherever they are, even thousands of miles away from their hiding place, for example in the Tora Bora caves in Afghanistan that has become their makeshift Pentagon (Chua, 2009).

The impact is that it is this dissatisfaction that often triggers conflict, what more when the poor people see others leading a better life compared to their own. In line with Thomas Hobbes's phrase "war all against all", humans naturally are selfish and tend to go into conflicts. International relations that are anarchic by nature happen when there is no government that can control humans to avoid dispute. This anarchic approach refers to the exclusion of any form of country, coercing government and any form of domination and exploitation. It is an assumption about free and equal access towards all world resources "to enable positive freedom (freedom to) in place of negative freedom (freedom from) or the basis for most of the constitutional rights". Most anarchists operate on the opposition principle without leaders or work independently without the knowledge or support of other members of the group or society. This group contributes to the idea that murder or "murder-suicide", determines the highest form of revolutionary fights. This group also supports the use of destructive weapons at a grand scale (Beiner, 2006).

The Association between Globalisation and the Rise of Violent Movements and Resistance Globalisation is a term that has always been talked about especially at the end of the Cold War but if we look at it closely there are implications and connections that is attached to the framework put forth by Baylis \& Smith (1997), that globalisation that has always been seen 
negatively, more or less invites the sense of discontent and resistance through what is seen as the domination of economic interests and the western culture on others in the world. Some of the impacts of globalisation that increases resistance are as elaborated briefly below:

1. The globalisation of poverty threatens not only to erode human security but also to weaken the globalisation itself. When globalisation inequality divides the world and the countries to the polarised zones of wealth and poverty, "inclusion and exclusion, empowerment dan disempowerment", it spawns a world order fragmentation that sees an increase in the number of countries that fail, transnational terrorism, also increased fundamentalism, organised crime and ethnic and religious conflicts (Held \& McGrew, 2002).

2. The diminishing power that has been possessed by nation-states due to the surge of globalisation has facilitated the emergence of systematic crime groups and other antiglobalisation movements. This has a relation with the aspect of global governance that argues, to whom are these social movements and transnational organisations accountable to (Mittelman, 2000; Holton, 1998).

These are the two of the studies that have focused on the resistance-oriented movements and impacts of globalisation.

\section{The Factors of Ideology and Process Factors}

The factor of ideology plays a significant role in igniting violence. It refers briefly as a set of arranged ideas, values and principles and it has aims to gain power and political influence. It also involves a pattern of thoughts and beliefs. According to Destutt de Tracy, an ideology can be recognised with these characteristics-firstly, it contains a wide explanatory theory about human experience and the external world; secondly, it represents a general and abstract program about social and political organisation; thirdly, it portrays the truth of the idea as a need or validates the fight; and finally as directed at the public, but it is possibly more prone to give specific leadership tasks to the intellects. There are various ideologies. Some of the popular ones include liberalism, communism, conservatism, Islamism, Fascism, nationalism and so on. According to history, the Marxism-Leninism school of thought has been proven to be very appealing to individuals who are looking for a framework that enables them to understand not only why injustice happened but also how this injustice can be ended. Thus, these terrorists are "true believers", worshipping the idea that a good society can only be created if specific obstacles or threats can be extinguished. For Marxist-Leninists, this threat comes from the bourgeoisie and for the Fascists, the threat comes from the minority or the immigrants; for nationalists, the threat is colonial-based, whereas for religious extremists, it is not only the foreigners but also the values they represent that are deemed malicious to the nobility of the religion.

The Fascist political understanding refers to the unity of all economic and political power into one form of racism that concentrates on the elimination of race or war and on-going violence to achieve perfection and the sanctity of a race or people (Beiner, 2006; Passmore, 2002). Their understanding stresses on a radical, aggressive nationalism that makes its leaders a cult, the latter of whom demand for absolute loyalty as can be seen through Benito Mussolini, Adolf Hitler, Kim Joun II. Fear, physical violence and the myth of soul-searching and renewal have reignited the grandiosity of Rome and "promised national rebirth" (Freeden, 2003) and 
in the context of North Korea, the unity of the Korean race based on the Juche ideology (Cha, 2012).

Different from anarchy, Fascism supports terrorism within and outside the country. Fascism exploits the disappointment of the race and makes them feel that they are more superior to others. When intertwined with their bearings that lean more towards being anti-Western, this school of thought has become a social identity instrument and the prime mover of terrorism against all Western interests. The fascists who are disappointed in their failure to gain control in their own country, according to history, have shifted to domestic terrorism as a tool for them to bring down their enemies. They do not believe that all humans have the same rights (Beiner, 2006). From this angle, the researcher feels that this approach is not appropriate to be studied as it focuses on the internal condition of a country.

Finally, there is the process or the selective interpretation on the religious texts in justifying and supporting their activities especially by the fundamentalists or militants. Issues related to puritanism on a sect and the acculturations of religious leaderships have contributed to the misinterpretation of religious teachings. Most of the traditions related to the compliance to religious teachings are full of images of violence and destruction, or self-destruction becoming the gist of the logic behind religious-based terrorism. This form of extremism can also be rather extreme in terms of the tactic used. Not only that it becomes vengeful towards a long saga of injustice and oppression, but it also often conducts pre-emptive strikes or attacks. This is evident when the romanticism towards the Crusade aged almost 1000 years is replayed by the preachers or crusaders of Islam and Christian to gain support for their respective groups. The issue of separatism in the name of religion has also been manipulated in demanding for autonomous territories or independence from the central government, for example through the setting up of a separatist group or Muslim minority in the southern Thai which is Pattani United Liberation Organization (PULO)

(https://www.cfr.org/backgrounder/muslim-insurgency-southern-thailand). A similar case is seen in the Muslim minority in the south of the Philippines who also forms their own group and movement for instance Moro National Liberation Front (MNLF) founded by Nur Misuari since 1972 and a more radical and weapon-equipped group like the Abu Sayyaf group.( https://rlp.hds.harvard.edu/faq/moro-national-liberation-front).

These separatists mostly come from the reaction over the assimilation process done by the ruling power other than fighting to defend their identity and culture. It has to be mentioned here, however, that the gathering of this type of militants only uses terrorism as their last tactic (Beiner, 2006). Religious factor also plays an important role in motivating violence, where there are two dimensions, the first of which is external or specifically religion vs religion, and the second one is internal which is religion vs sect. In the war context that is inter-faith can be seen classically in the Crusade between Christians and Muslims in fighting for the Holy Land of Jerusalem. According to the historical record, almost 1.7 million lives have been robbed in the war. Also, in the classical history, violence related to the sectarian fights and disputes can be seen in the Gunpowder Plot in 1605 when there was an attempt by Catholic extremists to set a bomb in the British Parliament. Although the plan was failed, it was an attempt that was very well-known in modern history. However, the sectarian war issues among sects are very popular, for instance The St. Bartholomew's Day Massacre in 1572 when the Christian Catholic committed a planned attack on the Protestants in France costing the lives of five thousand to thirty thousand lives. Additionally, according to scholars like Viotti 
\& Kauppi (1997) there are some extreme fanatics in religious groups- for instance in the case of sect extremists in Jewish religion known as the Zealots group, that emerged in the year 100 $A D$ have annihilated local government officers and committed the guerrilla warfare in the effort to ignite chaos and oust Roman rulers out of their homeland. This can be detailed in the rebellious incident of Bar Kokhba.

Other than that, the Middle Eastern region also produces Assassins (1090-1275), comprising of Shiah-sect Muslims who had assassinated political rivals especially Sunni political leaders for instance Nizam Al Mulk the Prime Minister of Abbasiyah government, and government officers. Through history, most of the terrorism activities committed in the traditional activities were religion-inspired. These terrorists often claim that they are actually obeying God's commands. These examples are religious-inspired terrorism, which is not a crucial issue these days despite it being something new (Viotti \& Kauppi, 1997).

According to the perspective of Huntington (1996) and Lewis (1993), future conflicts or violence will be driven by the clash of civilizations. Islamic Civilization will collide with the Western Civilization following the Crusade 1000 years ago. The thesis by Huntington appears to be a reality when the incident on 11 September 2001 happened where terrorists have launched an attack on the US in the name of religion. The repercussion from the event is seen in the grand-scale state of Islamophobia. Terrorist groups such as Taliban, al Qaeda, Boko Haram and the latest Daesh or IS aim to create a Global Islamic state and fights against nonbelieving Western countries like the US. The US attack on Afghanistan in 2001 and Iraq 2003 had created a chain reaction with religious nuances, and in the context of South East Asia, the bombing incident in Bali that had taken the lives of 102 people. Jemaah Islamiah (JI) was believed to have been involved in the attack as they were not happy with the US's action in attacking Afghanistan and Iraq. Meanwhile, on 17 July 2009, Indonesia again, was shocked by the terrorists' attack around Jakarta involving some hotspot locations around JW Marriot Hotel involving 9 fatalities and 50 more injured. The involvement of Britain and US Affiliated in military operations in Iraq and Afghanistan has made the former the target of bomb attack by radical Islamists. On 7 July 2005, the city of London was alarmed by explosion leading to 37 fatalities and 700 more injured (https://www.nytimes.com/2005/07/08/world/europe/subway-and-bus-blasts-in-londonkill-at-least-37.html)

Additionally, the latest is the terrorist attack on Paris city in November 2015 taking the lives of 130 people and 494 more reported as injured. Daesh ISIL admitted to have committed the attack (https://edition.cnn.com/2015/11/13/world/paris-shooting/index.html). The attack has become so dominant and it was carried out by non-state actors, which is a religiouslyshadowed radical organisation. They have abused the term jihad as the justification in committing murder and attacks. According to several studies, most terrorists are involved because they are inspired by the religious teaching, causing them to commit to the activity. In reality, the fanatics are believed to seek for the shortcut to Heaven by using 'words of war' in the Quran to legitimise their action without really looking into the context and only take the verses at face value. These include the verses of al Baqarah, 2: '190; al-Tawbah, 9: 39, 123; al-Zumār, 39: 79 (Mubarak, 2012). They also easily committed activities like suicide attacks as they are the easiest and the most effective in committing violence towards the public. The education system and political party that are ultra conservative and radical also play a part in 
the violent activities. This is evident in the Malaysian context such as the Mamali incident in 1985 and the Bukit Jenalik incident committed by the Al Maunah in 2000. The movement is said to be inspired by the ambition to bring down the Malaysian government that they deem deviant and it was to be replaced by Islamic system and sovereignty. Up until 2003, the Malaysian authority has arrested more than 70 suspects said to be involved in associations such as Kumpulan Militan Malaysia (KMM) and also Jemaah Islamiah under the Internal Security Act (ISA) (https://www.pgtar.com.my/lokal/semasa/2008/12/11/anggota-ji-bantuperancang-11-sept-bebas-isa).

In Islam it is an offence and it is haraam if the attack is targeted at the innocent people as shown in several examples of violent attacks as mentioned above. According to the religious sociology scholars, religion in a given condition urges towards peace-making, affiliation and solidarity but in another given condition it portrays itself as something fierce, heinous and spreading conflicts as dictated in history as the contributing factor of war. Religion is not only the integrating factor but also the disintegrating one (Kahmad, 2002).

According to Dawkins (2006), almost all violent activities are inspired from exclusive and dogmatic religious teachings. Faith is not only rational, but it also encourages towards the spread and aspiration of martyrdom. For a man, if religion requires him to implode and believes that God will grant him Heaven and salvation, he is willing to do it. Even a lot of religious leaders have taken advantage of their idolising followers for personal interests including committing violence, boycotting and committing mass murder. The latest is the case in Myanmar when some extremists comprising of Buddhist monks supported by soldiers were involved in the movements of abolishing, boycotting and committing violence on the ethnic Rohingya which is a Muslim ethnic and who have been living in the area for generations (https://theconversation.com/myanmar-and-buddhist-extremism-86125).

\section{Conclusion}

The 11 September incident has brought to the redefinition and repositioning of terrorism. AS has openly admitted to Huntington's thesis about the clash of civilizations in the macro aspect which is between the Islamic and the Western civilizations. Even the existence of several nonstate actors like Al Qaeda, Daesh or IS has offered a picture that these actors can even defy state actors. If the US previously focused on state terrorism like Soviet Union and the postcollapse of the Berlin Wall, Iran and North Korea are seen as less of a threat compared to Al Qaeda and IS. Regionally, there are also groups of terrorists like Abu Sayaf, JI and so on. The globalisation issue has rendered terrorism activities to happen more easily other than the fact that the issues of economic inequality have impacted the stability of domestic politics and the failure of global economic institutions like IMF and World Bank in the effort to bridge this inequality gap.

The identity and religious-based political resurgence has also contributed to violent activities. This clash is explained by the US efforts to spread the democratic ideology and westernization is said to have eroded local identity values and religious values especially Islam, as the reaction towards the puritan, radical and extreme religious groups who want to defend their religious beliefs. The economic factor also plays its role because some of the developed countries also the developing and the less developed ones have been uneasy with each other's economic achievements. Economic inequality at the domestic and global levels has its 
link with political violence or terrorism that is currently becoming a global political trend. Recently, Biden's victory over Trump still cannot put a stop to this violence but it has even turned to domestic terrorism when the crime of hate and racism has increased drastically in the US with the occurrences of attacks on the Black people and Asian Americans.

\section{References}

Bacevich, A. J. (2001). Between the Lines: Terrorizing the Truth. Foreign Policy, 125, 74-75.

Barro, R. J. (2002). The Myth That Poverty Breed Terrorism. Business Week, 3786.

Baylis, J., \& Smith, S. (1997). The Globalization of World Politics: An Introduction to International Relations. New York: Oxford University Press.

Beiner, R. (2006). The Criminology of Terrorism: Theories and Models. http://www.spartacus.schoolnet.co.uk/USAanarchist.htm (8 October 2017).

Blum, W. (2007). Negara Sapgeng; Membuka Topeng Amerika. Kuala Lumpur. ITBM http://encyclopedia.thefreedictionary.com/Americanization (12 November 2009).

Booth, K., \& Dunne, T. (2002). Worlds in Collision: Terror and the Future of Global Order. New York: Palgrave Macmillan.

Cha, V. (2012). The Impossible State: North Korea, Past and Future. London: The Bodley Head.

Chua, A. (2009). Day of Empire: How Hyperpowers Rise to Global Dominance--and Why They Fall. New York: Doubleday.

Dawkins, R. (2006). The God Delusion. New York: Bantam Books.

Freeden, M. (2003). Ideology: A Very Short Introduction. New York: Oxford University Press.

Fukuyama, F. (1992). The End of History and the Last Man. New York: Free Press.

Guelke, A. (1995). The Age of Terrorism and The International Political System. London; New York: Tauris Academic Studies.

Held, D., \& McGrew, A. (2002). Globalization and Anti-Globalization. Cambridge: Polity Press.

Holton, R. J. (1998). Globalization and the Nation State. London: Macmillan Press.

Huntington, S. P. (1996). The Clash of Civilizations and the Remaking of World Order. New York: Simon \& Schuster.

Huntington, S. P. (1997). Peradaban Barat: Unik, dan Bukan Sejagat. Jurnal Pemikir, 1-22.

Jones, A. (2006). Dictionary of Globalization. Cambridge: Polity Press.

Kahmad, H. (2002). Sosiologi Agama. Bandung, PT: Remaja Rosdakarya.

Kegley, C. W. (2003). The New Global Terrorism: Characteristics, Causes, Controls. New Jersey: Prentice Hall.

Krueger, A. B., \& Maleckova, J. (2002). Does Poverty Cause Terrorism? The New Republic, 226(24), $27-39$.

Lewis, B. (1993). Islam and the West. Oxford University Press.

Mansbach, R. W. (2000). Global Puzzle: Issues and Actors in World Politics (3rd ed.). Boston; New York: Houghton Mifflin Harcourt.

Mittelman, J. H. (2000). The Globalization Syndrome. New Jersey: Princeton University Press.

Mubarak, Z. (2012). Fenomena terorisme di Indonesia: Kajian Aspek Teologi, Ideologi dan Gerakan. Jurnal Studi Masyarakat Islam, 15(2), 240 - 254.

Othman, N. (2006). Global terorisme: Ancaman Terhadap Kedaulatan Negara-Negara ASEAN. In Hanizah Idris (editor) Asia Tenggara Kontemporari. Kuala Lumpur: Penerbit Universiti Malaya.

Roskin, M. G., \& Berry, N. O. (1999). The New World of International Relations (4th ed.). New Jersey: Prentice Hall.

Scholte, J. A. (2000). Globalization: An Introduction. New York: St. Martin's Press. 
Stiglitz, J. E. (2002). Globalization and Its Discontents. New York: W. W. Norton \& Company. The Moro National Liberation Front. https://rlp.hds.harvard.edu/faq/moro-nationalliberation-front.

Viotti, P. R., \& Kauppi, M. V. (1997). International Relations and World Politics: Security, Economy, Identity. New Jersey: Prentice Hall.

White, J. R. (1991). Terrorism: An Introduction. Pacific Grove, California: Brooks/ Cole Publishing Company.

Yazid, M. N. (2017). Asia Pasifik Sejak 1945; Perubahan Struktur Antarabangsa dan Percaturan Politik Serantau. Kuala Lumpur: Institut Terjemahan \& Buku Malaysia. 